\title{
The role of mast cells in cancers
}

\author{
Thiago T. Maciel ${ }^{1-5}$, Ivan C. Moura ${ }^{1-5}$ and Olivier Hermine $e^{1-6 *}$
}

Addresses: ${ }^{1}$ INSERM UMR 1163, Laboratory of cellular and molecular mechanisms of hematological disorders and therapeutic implications, 24 Boulevard du Montparnasse, 75015, Paris, France; ${ }^{2}$ Paris Descartes - Sorbonne Paris Cité University, Imagine Institute, 24 Boulevard du Montparnasse, 75015, Paris, France; ${ }^{3}$ CNRS ERL 8254, 24 Boulevard du Montparnasse, 75015, Paris, France; ${ }^{4}$ Laboratory of Excellence GR-Ex, 24 Boulevard du Montparnasse, 75015, Paris, France; ${ }^{5}$ Centre de Référence National des Mastocytoses (CEREMAST), 149 rue de Sèvres, 75015 , Paris, France; ${ }^{6}$ Service d'Hématologie clinique, Assistance Publique-Hôpitaux de Paris, Hôpital Necker, 149 rue de Sèvres, 75015, Paris, France

* Corresponding author: Olivier Hermine (ohermine@gmail.com)

Fl000Prime Reports 2015, 7:09 (doi:10.12703/P7-09)

All FI000Prime Reports articles are distributed under the terms of the Creative Commons Attribution-Non Commercial License (http://creativecommons.org/licenses/by-nc/3.0/legalcode), which permits non-commercial use, distribution, and reproduction in any medium, provided the original work is properly cited.

The electronic version of this article is the complete one and can be found at: http://fl000.com/prime/reports/m/7/9

\begin{abstract}
Mast cells are immune cells that accumulate in the tumors and their microenvironment during disease progression. Mast cells are armed with a wide array of receptors that sense environment modifications and, upon stimulation, they are able to secrete several biologically active factors involved in the modulation of tumor growth. For example, mast cells are able to secrete pro-angiogenic and growth factors but also pro- and anti-inflammatory mediators. Recent studies have allowed substantial progress in understanding the role of mast cells in tumorigenesis/disease progression but further studies are necessary to completely elucidate their impact in the pathophysiology of cancer. Here we review observations suggesting that mast cells could modulate tumor growth in humans. We also discuss the drawbacks related to observations from mast cell-deficient mouse models, which could have consequences in the determination of a potential causative relationship between mast cells and cancer. We believe that the understanding of the precise role of mast cells in tumor development and progression will be of critical importance for the development of new targeted therapies in human cancers.
\end{abstract}

\section{Context}

Interaction between cancer cells and their microenvironment are multiple and can result in both progression and arrest of tumor growth [1]. Tumor microenvironment is composed of stromal cells but also of cells from both innate (i.e. neutrophils, macrophages, mast cells, myeloid-derived suppressor cells, dendritic cells and natural killer lymphocytes) and adaptive ( $\mathrm{T}$ and $\mathrm{B}$ lymphocytes) arms of the immune system. Moreover, lymphocytes and tumor-associated macrophages (TAMs) are the major cellular populations present in infiltrates in well-established tumors. In this setting, the extent of type 1 helper (Th1) effector CD8+ cells has been shown to be a marker of clinical response suggesting that, in particular conditions, immune cells can exert anti-tumor effects $[2,3]$. In contrast to $T$ cells, it has been shown that TAM infiltrates correlate to a poor prognosis in the majority of cancers, but positive associations between TAMs and disease prognosis have been also proposed [4]. Differences in the impact of TAMs in cancer prognosis are probably related to their plasticity, since macrophages can adopt different phenotypes depending on the cellular context [4]. Recently, clinical trials in melanoma patients have shown that the manipulation of tolerance by the combined use of monoclonal antibodies directed against immune-checkpoint inhibitors (i.e. CTLA- 4 and PD-1) resulted in effective responses and a proportion of patients presented an improved overall survival [5]. Therefore, immunemodulatory molecules could subvert the complex interactions between tumors and immune cell infiltrates, therefore favoring anti-tumor responses.

Mast cells are cells of hematopoietic origin which terminally differentiate and become mature in tissues [6]. They can contribute to both innate and adaptive immune responses and therefore represent potential players in 
different physiopathological conditions $[7,8]$. The presence of mast cells at the periphery, but also infiltrating tumors, argues for their role in the modulation of tumor biology [9]. Therefore, the crosstalk between mast cells and other tumor-infiltrating cells appears to be a potential target for anticancer therapies. In this review, we summarize some of the observations about the presence of mast cells in human tumors and the contribution of mouse models to the understanding of the complex relationships between these components of disease pathology.

\section{Mast cell responses to environmental threats}

Mast cells are long-lived secretory cells viewed as sentinels, able to rapidly respond to modifications in their environment $[8,10,11]$. Their ability to respond to extrinsic signals relies on the surface expression of a wide array of receptors, such as Toll-like receptors (TLRs) [12] and Nod-like receptors (NLRs) [13], as well as FC and complement receptors [14-16]. Upon activation, mast cells have the ability to secrete a wide array of inflammatory mediators. These can be released from pre-stored sources in cytoplasmic granules, such as histamine and unique mast cell proteases, with an immediate effect [17]. Others factors, including prostaglandins, leukotrienes, as well as a whole set of inflammatory cytokines and chemokines, are newly synthesized $[8,10]$. Mast cells can also shift their phenotype depending on the duration of stimuli exposition. For example, it has been shown that an acute activation of the transcription factor aryl hydrocarbon receptor (AhR) in mast cells stimulates IgE-dependent mast cell activation resulting in increased histamine secretion, as well as the production of interleukin (IL)- 6 and IL-13, whereas prolonged exposure to AhR ligands resulted in a shift to IL-17 responses and impaired mast cell degranulation $[18,19]$. Moreover, mast cells can be presented in different subtypes in accordance with their tissue distribution (e.g. connective tissue-type and mucosal mast cells), which can vary according to the genetic background of individuals resulting in "mast cell plasticity" [9].

Once secreted, mast cell mediators can do the following: (a) initiate tissue and immunological responses; (b) attract inflammatory cells; (c) mediate tissue remodeling and repair $[8,10,11,20]$. Differences in response lie in the ability of mast cells to secrete proinflammatory (mainly tumor necrosis factor [TNF]- $\alpha$ ) or anti-inflammatory (IL-10 and transforming growth factor [TGF- $\beta$ ]) cytokines. For example, mast cells are able to secrete TNF- $\alpha$ and increase antigen presentation by dendritic cells, promoting pro-inflammatory $\mathrm{T}$ cell responses and monocyte/macrophage activation $[7,8]$. However, under specific conditions, mast cells can secrete IL-10 and thus block T cell proliferation $[7,8]$. Moreover, mast cells can modulate adaptive immunity and angiogenesis $[7,21]$ through the release of cytoplasmic granules and cytokines (mainly IL- 1, TNF- $\alpha$, IL-6) and growth factors (vascular endothelial growth factor [VEGF], TGF- $\beta$, fibroblast growth factor-2 [FGF-2], angiopoietin-1). Therefore, mast cells can modulate the intensity of organ injury depending on the pathophysiological context [22]. Although often studied for their effector functions in allergy and asthma $[23,24]$, it has recently been suggested that mast cells have detrimental functions in several other inflammatory conditions, such as multiple sclerosis (MS), rheumatoid arthritis (RA), and inflammatory bowel disease (IBD) [25-27]. However, the roles of mast cells in inflammatory diseases have been recently challenged by the use of newly characterized mast cell-deficient mice $[28,29]$.

\section{The role of mast cells in tumors: what can we learn from human studies?}

Increased accumulation of mast cells within tumor environments has been correlated with poor prognosis, increased metastasis and reduced survival in several types of human cancer, including melanoma [30], prostate [31], pancreatic adenocarcinoma [32], squamous cell carcinoma [33], Hodgkin lymphoma [34] and B-cell chronic lymphocytic leukemia $[35,36]$.

Tumor cells produce inflammatory mediators and proangiogenic factors, including stem cell factor (SCF). SCF is the ligand for CD117, also known as KIT receptor, a tyrosine kinase receptor highly expressed by mast cells [20]. Activation of SCF/Kit pathway is necessary for the maturation, migration and survival of mast cells [37], since they derive from hematopoietic precursors inside the bone marrow and complete their differentiation and maturation within vascularized tissues [38]. The surrounding environment of tumors, through SCF chemotaxis, promotes infiltration and maturation of mast cells, which release angiogenic mediators, proteases and growth factors that support tumor development [39]. It has been demonstrated that FGF-2 and VEGF derived from mast cells trigger an intense angiogenic response in vivo [40]. In agreement, accumulation of mast cells is usually found in the proximity of CD31+ cells and microvessels $[32,41]$.

Mast cells also release proteases within tumor environment. For example, tryptase activates latent metalloproteinases, contributes to extracellular matrix degradation, vascular tube formation and release of trapped angiogenic factors [42], promoting angiogenesis and metastasis. During tumor progression, mast cells also act on recruitment of neutrophils and eosinophils, activation of $\mathrm{T}$ and B immune responses [43], and myeloid-derived suppressor cells, which accumulate in the tumor microenvironment and correlate with poor prognosis [44]. 
Therefore, mast cells can exert pro-tumor effects by influencing the microenvironment or, directly, by conditioning the fate of tumor cells including drug resistance. They can promote tumor growth by inducing angiogenesis and promote tissue remodeling through the induction of changes in composition of the extracellular matrix [45]. Mast cells can also promote pro-inflammatory pathways that could result in the impairment of tumor progression [46]. The ability of mast cells to rapidly sense the environment could determine the resultant immune responses to tumors. By their ability to contribute to both innate and adaptive responses, mast cells can therefore modulate the outcome of major immune infiltrates present in tumors (i.e. TAM and lymphocytes). Therefore, we believe that targeting the survival/function of mast cells could influence cancer cells' behavior and therefore the outcome of clinical responses.

\section{Lessons from mouse models}

The accumulated knowledge on mast cell biology has been improved substantially with the discovery of mice models with mutations or deletions on c-kit gene (especially WBB6F1-Kit ${ }^{\mathrm{W} / \mathrm{W}-\mathrm{v}}$ and C57BL/6-Kit ${ }^{\mathrm{W}-\mathrm{sh} / \mathrm{W}-\mathrm{sh}}$ ), in which mast cell density or activity are significantly reduced $[21,29]$. Recent publications used rather C57BL/ $6-\mathrm{Kit}^{\mathrm{W}-\mathrm{sh} / \mathrm{W} \text {-sh }}$ mice for evaluation of mast cells, mainly because these mice have fewer defects compared to WBB6F1-Kit ${ }^{\mathrm{W} / \mathrm{W}-\mathrm{v}}$, are fertile, and have normal red blood cell counts [47]. Using C57BL/6-Kit ${ }^{\mathrm{W}-\mathrm{sh} / \mathrm{W}-\mathrm{sh}}$ mice, Pittoni et al. showed that mast cells (and more specifically mast cell-derived matrix metallopeptidase 9 [MMP-9]) are necessary and sufficient to promote tumor growth in mice subcutaneously grafted with adenocarcinoma cells [48]. Interestingly, pharmacological targeting of mast cell function by sodium cromoglycate (cromolyn) in mice expressing the transgenic adenocarcinoma of the mouse prostate (TRAMP) resulted in a paradoxical increase in both the incidence and aggressiveness of tumors, suggesting that environmental mast cells can exert proor anti-tumor effects depending on the cellular context [48]. The same experimental approaches were used by Soucek et al. to show that mast cell infiltrates support tumor growth and angiogenesis in a model of Mycinduced pancreatic $\beta$-cell tumors [49]. By using models of mice with genetic lesions in mast cell development, Gounaris et al. demonstrated that mast cells can support polyposis formation, which precedes colon cancer development [50]. Moreover, Yang and colleagues have shown that loss of neurofibromatosis type 1 (NF1) gene in mast cells is required for neurofibroma growth, and that targeting KIT activity by imatinib mesylate decreases tumor development in mice: this strategy was effective in the treatment of a young neurofibromatosis patient [51]. In addition to these discussed models, mast cells have been shown to play a harmful role on other types of tumors, including B16F10 melanoma, dimethylhydrazine (DMH) induced colonic epithelial neoplasms, $\mathrm{M}$ B49 bladder carcinoma cells and T-cell lymphoma EL4 cells [52-55]. Altogether, the use of mouse models of impaired KIT function have contributed to our better understanding of the role of mast cells on tumor biology, with experimental evidence that mast cells contribute to metastasis, malignant neovascularization and release of pro-angiogenic proteases and growth factors [9]. Therefore, this evidence suggests that mast cells may support tumor growth from different cellular origins, suggesting that targeting mast cell functions could be a therapeutic option in cancer treatment either alone or in combination with chemotherapy.

Recently, Puwar et al. showed that recombinant IL-9 (rIL-9) displays a highly potent anti-tumor effect both in melanoma and lung carcinoma models and that this effect is lost in C57BL/6-Kit ${ }^{\mathrm{W}-\mathrm{sh} / \mathrm{W}-\mathrm{sh}}$ mice [56], suggesting mast cells are required for the therapeutic efficacy of rIL-9, and opening new perspectives in the understanding of the mast cell function in tumors. However, further studies will be necessary to better elucidate the complexity of mast cell functions in tumor biology.

Results obtained with KIT-dependent mast cell-deficient mice should be viewed with caution, since these mice also present other abnormalities related to c-kit mutations, which may affect other cells involved in tumor progression (including natural killer $[\mathrm{NK}]$ and dendritic cells) $[57,58]$. Recently, several new mouse models have been published, aiming to abolish mast cells without impairment of KIT function $[28,29,59,60]$. These experimental models could help to better elucidate the role of mast cells in tumor progression. However, these models also have drawbacks, since the abnormalities are not exclusively specific to mast cells. Moreover, to date there are no pharmacological compounds able to target mast cells specifically [9].

\section{Concluding remarks}

To date the role of mast cells in tumors has been largely ignored. This is particularly due to the debatable evidence of a causal relationship between mast cell infiltrates and tumor progression in humans. In addition, the use of mast cell-deficient models has been recently challenged by the characterization of new specific models of mast cell ablation $[21,29]$. Therefore, the role of mast cell infiltrates in tumors is still unclear and merits particular attention. Unveiling complex interactions between mast cells, microenvironment and tumors could provide insights into the understanding of disease pathogenesis. This may open new avenues in expanding the arsenal of 
targeted therapies aiming to induce tumor growth arrest and tumor cell response to chemotherapy.

\section{Abbreviations}

AhR, aryl hydrocarbon receptor; IL, interleukin; SCF, stem cell factor; TAM, tumor-associated macrophage; TGF- $\beta$, transforming growth factor; VEGF, vascular endothelial growth factor.

\section{Disclosures}

Olivier Hermine is a co-founder of ABscience. Thiago T. Maciel is an employee of ABscience.

\section{Bibliography}

I. Joyce JA: Therapeutic targeting of the tumor microenvironment. Cancer Cell 2005, 7:5 13-20.

2. Pagès $F$, Galon J, Dieu-Nosjean $M$, Tartour $E$, Sautès-Fridman C, Fridman W: Immune infiltration in human tumors: a prognostic factor that should not be ignored. Oncogene 2010, 29:1093-102.

3. Pagès $F$, Berger A, Camus M, Sanchez-Cabo F, Costes A, Molidor R, Mlecnik B, Kirilovsky A, Nilsson M, Damotte D, Meatchi T, Bruneval P, Cugnenc P, Trajanoski Z, Fridman W, Galon J: Effector memory T cells, early metastasis, and survival in colorectal cancer. $N$ Engl J Med 2005, 353:2654-66.

\section{FlOOOPrime \\ RECOMMENDED}

4. Qian B, Pollard JW: Macrophage diversity enhances tumor progression and metastasis. Cell 2010, I4I:39-5I.

5. Wolchok JD, Kluger $\mathrm{H}$, Callahan MK, Postow MA, Rizvi NA, Lesokhin AM, Segal NH, Ariyan CE, Gordon R, Reed K, Burke MM, Caldwell A, Kronenberg SA, Agunwamba BU, Zhang X, Lowy I, Inzunza HD, Feely W, Horak CE, Hong Q, Korman AJ, Wigginton JM, Gupta A, Sznol M: Nivolumab plus ipilimumab in advanced melanoma. N Engl J Med 20I3, 369: I22-33.

\section{FlOOOPrime}

6. Ribatti D, Crivellato E: Mast cell ontogeny: an historical overview. Immunol Lett 2014, 159: I -4.

7. Galli SJ, Grimbaldeston M, Tsai M: Immunomodulatory mast cells: negative, as well as positive, regulators of immunity. Nat Rev Immunol 2008, 8:478-86.

\section{FlOOOPrime} RECOMMENDED

8. Marshall JS: Mast-cell responses to pathogens. Nat Rev Immunol 2004, 4:787-99.

9. Marichal T, Tsai M, Galli SJ: Mast cells: potential positive and negative roles in tumor biology. Cancer Immunol Res 2013, I:269-79.

10. Galli SJ, Nakae S, Tsai M: Mast cells in the development of adaptive immune responses. Nat Immunol 2005, 6: I35-42.

II. Gurish MF, Austen KF: The diverse roles of mast cells. J Exp Med 200I, 194:FI-5.

12. Marshall JS, McCurdy JD, Olynych T: Toll-like receptor-mediated activation of mast cells: implications for allergic disease? Int Arch Allergy Immunol 2003, 132:87-97.

13. Anders $\mathrm{H}$, Muruve DA: The inflammasomes in kidney disease. J Am Soc Nephrol 20II, 22:1007-18.

14. Ali $\mathrm{H}$ : Regulation of human mast cell and basophil function by anaphylatoxins C3a and C5a. Immunol Lett 20I0, I 28:36-45.

15. Malbec O, Daëron M: The mast cell IgG receptors and their roles in tissue inflammation. Immunol Rev 2007, 217:206-2I.
16. Rivera J, Fierro NA, Olivera A, Suzuki R: New insights on mast cell activation via the high affinity receptor for IgE. Adv Immunol 2008, 98:85- 120

17. Blank $U$, Rivera J: The ins and outs of IgE-dependent mast-cell exocytosis. Trends Immunol 2004, 25:266-73.

18. Sibilano R, Frossi B, Calvaruso M, Danelli L, Betto E, Dall'Agnese A Tripodo C, Colombo MP, Pucillo CE, Gri G: The aryl hydrocarbon receptor modulates acute and late mast cell responses. J Immunol 20I2, 189:I20-7.

\section{FlOOOPrime} RECOMMENDED

19. Sibilano R, Pucillo CE, Gri G: Allergic responses and aryl hydrocarbon receptor novel pathway of mast cell activation. Mol Immunol 2014.

20. Maurer M, Theoharides T, Granstein RD, Bischoff SC, Bienenstock J, Henz B, Kovanen P, Piliponsky AM, Kambe N, Vliagoftis H, LeviSchaffer F, Metz M, Miyachi Y, Befus D, Forsythe P, Kitamura $Y$, Galli S: What is the physiological function of mast cells? Exp Dermatol 2003, | 2:886-9|0.

21. Rodewald H, Feyerabend TB: Widespread immunological functions of mast cells: fact or fiction? Immunity 2012, 37:13-24.

22. Knol EF, Olszewski M: Basophils and mast cells: Underdog in immune regulation? Immunol Lett 20II, I38:28-3I.

23. Kinet JP: The high-affinity IgE receptor (Fc epsilon RI): from physiology to pathology. Annu Rev Immunol 1999, I7:93 I-72.

24. Bradding $P$ : The role of the mast cell in asthma: a reassessment. Curr Opin Allergy Clin Immunol 2003, 3:45-50.

25. He S: Key role of mast cells and their major secretory products in inflammatory bowel disease. World J Gastroenterol 2004, 10:309-18.

FIOOOPrime

26. Secor VH, Secor WE, Gutekunst CA, Brown MA: Mast cells are essential for early onset and severe disease in a murine model of multiple sclerosis. J Exp Med 2000, 191:813-22.

FlOOOPrime

27. Lee DM, Friend DS, Gurish MF, Benoist C, Mathis D, Brenner MB: Mast cells: a cellular link between autoantibodies and inflammatory arthritis. Science 2002, 297:1689-92.

\section{FIOOOPrime \\ RECOMMENDED}

28. Feyerabend TB, Weiser A, Tietz A, Stassen M, Harris N, Kopf M, Radermacher P, Möller P, Benoist C, Mathis D, Fehling HJ, Rodewald H: Cre-mediated cell ablation contests mast cell contribution in models of antibody- and $\mathrm{T}$ cell-mediated autoimmunity. Immunity 20I I, 35:832-44.

\section{FlOOOPrime
RECOMMENDED}

29. Reber LL, Marichal T, Galli SJ: New models for analyzing mast cell functions in vivo. Trends Immunol 20I2, 33:6/3-25.

30. Ribatti D, Ennas MG, Vacca A, Ferreli F, Nico B, Orru S, Sirigu P: Tumor vascularity and tryptase-positive mast cells correlate with a poor prognosis in melanoma. Eur J Clin Invest 2003, 33:420-5.

\section{FlOOOPrime}

\section{FECOMMENDED}

31. Nonomura N, Takayama H, Nishimura K, Oka D, Nakai Y, Shiba M, Tsujimura A, Nakayama M, Aozasa K, Okuyama A: Decreased number of mast cells infiltrating into needle biopsy specimens leads to a better prognosis of prostate cancer. $\mathrm{Br} J$ Cancer 2007, 97:952-6.

\section{FlOOOPrime}

\section{RECOMMENDED}

32. Strouch MJ, Cheon EC, Salabat MR, Krantz SB, Gounaris E, Melstrom LG, Dangi-Garimella S, Wang E, Munshi HG, Khazaie K, Bentrem DJ: Crosstalk between mast cells and pancreatic 
cancer cells contributes to pancreatic tumor progression. Clin Cancer Res 2010, 16:2257-65.

\section{FIOOOPrime}

33. Elpek GO, Gelen T, Aksoy NH, Erdoğan A, Dertsiz L, Demircan A, Keleş $\mathrm{N}$ : The prognostic relevance of angiogenesis and mast cells in squamous cell carcinoma of the oesophagus. J Clin Pathol 200I, 54:940-4.

\section{FlOOOPrime}

\section{RECOMMENDED}

34. Glimelius I, Edström A, Fischer M, Nilsson G, Sundström C, Molin D, Amini R, Enblad G: Angiogenesis and mast cells in Hodgkin Iymphoma. Leukemia 2005, 19:2360-2.

35. Molica S, Vitelli G, Levato D, Giannarelli D, Vacca A, Cuneo A, Cavazzini $F$, Squillace R, Mirabelli R, Digiesi G: Increased serum levels of matrix metalloproteinase- 9 predict clinical outcome of patients with early B-cell chronic lymphocytic leukaemia. Eur J Haematol 2003, 70:373-8.

\section{FlOOOPrime}

36. Molica S, Vacca A, Crivellato E, Cuneo A, Ribatti D: Tryptase-positive mast cells predict clinical outcome of patients with early B-cell chronic lymphocytic leukemia. Eur J Haematol 2003, 7 I: I37-9.

\section{FlOOOPrime
RECOMMENDED}

37. Galli SJ, Tsai M, Wershil BK, Tam SY, Costa J]: Regulation of mouse and human mast cell development, survival and function by stem cell factor, the ligand for the c-kit receptor. Int Arch Allergy Immunol 1995, 107:51-3

38. Gurish MF, Austen KF: Developmental origin and functional specialization of mast cell subsets. Immunity 20I2, 37:25-33.

39. Huang B, Lei Z, Zhang G, Li D, Song C, Li B, Liu Y, Yuan Y, Unkeless J, Xiong $H$, Feng $Z$ : SCF-mediated mast cell infiltration and activation exacerbate the inflammation and immunosuppression in tumor microenvironment. Blood 2008, I I 2:1269-79.

\section{FlOOPrime}

\section{RECOMMENDED}

40. Norrby K, Jakobsson A, Sörbo J: Mast-cell secretion and angiogenesis, a quantitative study in rats and mice. Virchows Arch B Cell Pathol Ind Pathol 1989, 57:25I-6.

4I. Tóth-Jakatics R, Jimi S, Takebayashi S, Kawamoto N: Cutaneous malignant melanoma: correlation between neovascularization and peritumor accumulation of mast cells overexpressing vascular endothelial growth factor. Hum Pathol 2000, 3 I:955-60.

42. Blair RJ, Meng H, Marchese MJ, Ren S, Schwartz LB, Tonnesen MG, Gruber BL: Human mast cells stimulate vascular tube formation. Tryptase is a novel, potent angiogenic factor. J Clin Invest 1997, 99:2691-700.

43. Kinet J: The essential role of mast cells in orchestrating inflammation. Immunol Rev 2007, 2 I 7:5-7.

44. Saleem SJ, Martin RK, Morales JK, Sturgill JL, Gibb DR, Graham L, Bear HD, Manjili MH, Ryan JJ, Conrad DH: Cutting edge: mast cells critically augment myeloid-derived suppressor cell activity. J Immunol 20I2, I89:5 II-5.

\section{FlOOOPrime}

\section{RECOMMENDED}

45. Rüger B, Dunbar PR, Hasan Q, Sawada H, Kittelberger R, Greenhill N, Neale TJ: Human mast cells produce type VIII collagen in vivo. Int J Exp Pathol 1994, 75:397-404.

46. Ribatti D: Mast cells and macrophages exert beneficial and detrimental effects on tumor progression and angiogenesis. Immunol Lett 2013, 152:83-8.

\section{FlOOOPrime} RECOMMENDED

47. Grimbaldeston MA, Chen C, Piliponsky AM, Tsai M, Tam S, Galli SI: Mast cell-deficient W-sash c-kit mutant Kit W-sh/W-sh mice as a model for investigating mast cell biology in vivo. Am J Pathol 2005, 167:835-48.

\section{FlOOOPrime}

48. Pittoni P, Tripodo C, Piconese S, Mauri G, Parenza M, Rigoni A, Sangaletti S, Colombo MP: Mast cell targeting hampers prostate adenocarcinoma development but promotes the occurrence of highly malignant neuroendocrine cancers. Cancer Res $201 \mathrm{I}$, 7I:5987-97.

\section{FlOOOPrime
RECOMMENDED}

49. Soucek L, Lawlor ER, Soto D, Shchors K, Swigart LB, Evan GI: Mast cells are required for angiogenesis and macroscopic expansion of Myc-induced pancreatic islet tumors. Nat Med 2007, I3:I 2 I I-8.

\section{FlOOOPrime
RECOMMENDED}

50. Gounaris E, Erdman SE, Restaino C, Gurish MF, Friend DS, Gounari F, Lee DM, Zhang G, Glickman JN, Shin K, Rao VP, Poutahidis T, Weissleder R, McNagny KM, Khazaie K: Mast cells are an essential hematopoietic component for polyp development. Proc Natl Acad Sci USA 2007, 104:19977-82.

\section{FlOOOPRime
RECOMMENDED}

5I. Yang F, Ingram DA, Chen S, Zhu Y, Yuan J, Li X, Yang X, Knowles S, Horn W, Li Y, Zhang S, Yang Y, Vakili ST, Yu M, Burns D, Robertson K, Hutchins G, Parada LF, Clapp DW: NfI-dependent tumors require a microenvironment containing $\mathrm{NfI}+/-$ and c-kit-dependent bone marrow. Cell 2008, 135:437-48.

\section{FIOOOPrime}

\section{RECOMMENDED}

52. Starkey JR, Crowle PK, Taubenberger S: Mast-cell-deficient W/Wv mice exhibit a decreased rate of tumor angiogenesis. Int J Cancer 1988, 42:48-52.

53. Wedemeyer J, Galli SJ: Decreased susceptibility of mast celldeficient Kit(W)/Kit(W-v) mice to the development of I, 2-dimethylhydrazine-induced intestinal tumors. Lab Invest 2005, 85:388-96

\section{FlOOOPrime}

\section{RECOMMENDED}

54. Wasiuk A, Dalton DK, Schpero WL, Stan RV, Conejo-Garcia JR Noelle RJ: Mast cells impair the development of protective anti-tumor immunity. Cancer Immunol Immunother 2012, 6I:2273-82.

\section{FlOOOPrime
RECOMMENDED}

55. Rabenhorst A, Schlaak M, Heukamp LC, Förster A, Theurich S, Bergwelt-Baildon $M$ von, Büttner R, Kurschat $P$, Mauch $C$, Roers A, Hartmann K: Mast cells play a protumorigenic role in primary cutaneous lymphoma. Blood 2012, 120:2042-54.

\section{FlOOOPrime}

RECOMMENDED

56. Purwar R, Schlapbach $C$, Xiao $S$, Kang HS, Elyaman $W$, liang $X$, Jetten AM, Khoury SJ, Fuhlbrigge RC, Kuchroo VK, Clark RA, Kupper TS: Robust tumor immunity to melanoma mediated by interleukin-9-producing T cells. Nat Med 2012, I8:I248-53.

\section{FIOOOPrime
RECOMMENDED}

57. Borg C, Terme M, Taïeb J, Ménard C, Flament C, Robert C Maruyama K, Wakasugi H, Angevin E, Thielemans K, Le Cesne A, Chung-Scott V, Lazar V, Tchou I, Crépineau F, Lemoine F, Bernard J, Fletcher JA, Turhan A, Blay J, Spatz A, Emile J, Heinrich MC, Mécheri S, Tursz T, Zitvogel L: Novel mode of action of c-kit tyrosine kinase inhibitors leading to NK cell-dependent antitumor effects. J Clin Invest 2004, I | 4:379-88. 
58. Benson DM, Yu J, Becknell B, Wei M, Freud AG, Ferketich AK, Trotta R, Perrotti D, Briesewitz R, Caligiuri MA: Stem cell factor and interleukin-2/I5 combine to enhance MAPK-mediated proliferation of human natural killer cells. Blood 2009, I 13:2706-14.

\section{FlOOOPrime}

RECOMMENDED

59. Dudeck A, Dudeck J, Scholten J, Petzold A, Surianarayanan S, Köhler A, Peschke K, Vöhringer D, Waskow C, Krieg T, Müller W, Waisman A, Hartmann K, Gunzer M, Roers A: Mast cells are key promoters of contact allergy that mediate the adjuvant effects of haptens. Immunity 20II, 34:973-84.

\section{FlOOOPrime}

60. Lilla JN, Chen C, Mukai K, BenBarak MJ, Franco CB, Kalesnikoff J, Yu M, Tsai M, Piliponsky AM, Galli S): Reduced mast cell and basophil numbers and function in Cpa3-Cre; Mcl-Ifl/fl mice. Blood 20II, I I 8:6930-8.

FlOOOPrime

RECOMMENDED

